\title{
Thomas Heywood and the Portrayal of Female Benefactors in Post-Reformation England
}

In a modern era of scholarship, in which urban history and feminist history have come to the fore, Thomas Heywood's plays seem more relevant than ever: those two themes were critical to his work over the entire span of his long career. Though not a city-dweller by birth, some even of his earliest works, including an early version of The Four Prentices of London of the mid-1590s, exhibit the keen observation of the metropolitan milieu which marked all his subsequent work. The lost play Joan is as Good as My Lady, written in the winter of 1598-9 and just two years after the first reference to any of his writing, may have been his first substantial play heralding the role of women. That theme reached its ultimate, but far from last, expression in the better known The Fair Maid of the West. He was still exploring that theme in the last years of his active career. These and other works are filled with candid and often detailed observations about his own times, the urban milieu, and the woman's role. Thomas Heywood's play Ifyou Know Not Me, You Know Nobody has several times been cited as a social document of its time. ${ }^{1}$ Its central theme, most evident in the first part, is devoted to Queen Elizabeth, on whom the playwright doted. But the second part turns to other subjects close to his heart: charity, especially as exemplified by Hobson the noble haberdasher; civic benefactions, as exemplified by Sir Thomas Gresham's building of the Royal Exchange; and - albeit less conspicuously — women as noble benefactors in their own right.

New scholarly perspectives allow us to see new things. Heywood's play may well bear value for students of art history and social history; they may shed light on it in turn. This essay applies such additional perspectives by investigating what Heywood has had to say here about female benefactors, and about the contemporary use of portraiture in recognizing them and their benefactions.

In the second part of If You Know Not Me, Alexander Nowell, the Dean of St. Paul's, shows his guests through the picture gallery of his London town- 
house: 'a Gallery', he tells them, 'wherein I keepe the pictures of many charitable Citizens that ... You may by them learne to refresh your soules' (C4). Three of those citizens are men, former mayors and London heroes Sir John Philpot, Sir Richard ('Dick') Whittington, and Sir John Allen. But, somewhat surprisingly, two others are women: women who, in Nowell's words, also 'deseru'd a memory Worthy the note of our posterity' (D1). One is Agnes Foster, who helped her husband before the Reformation to establish a charity to ease the plight of prisoners in Ludgate; the other is Anne or 'Auice' ['Alice'] Gibson, who founded a free school at Ratcliffe and almshouses for fourteen poor people around $1540 .{ }^{2}$ One of Nowell's guests is Lady Mary Ramsey, wife of the London Master Grocer Sir Thomas Ramsey, Sheriff (1567-8) and then Lord Mayor (1577-8) of London, who had carried out substantial benefactions of her own. On seeing these examples of personal benefaction on Nowell's walls, she is struck by the two women portrayed. She asks why she herself should not be so remembered, so that 'My name might haue a register with theirs' (D1). It was a fair question in its time, and one which, as we will see, met with an appropriate response in real life. This oft-cited scene broaches a number of subjects of scholarly interest in several fields: the layout and furnishing of urban houses, the presumed domestic circumstances for an urban professional like Nowell, the nature of contemporary post-prandial entertainment, and so forth. But if we may take Heywood's observations as accurate, they also allow us to witness a contemporary social and cultural practice about which we are far less well informed: the use of portraiture to commemorate civic benefactions, and benefactions on the part of women as well as men. This essay measures the veracity of Heywood's scene against what relatively little we know about female benefactors, and the ways in which they may have been commemorated. Its conclusions shed light on what Heywood seems to have been doing in that scene, and therefore on the full value of the play as a social document of its time.

We do know that, in the civic world of post-reformation England, when most of the 'heroic' figures emanating from traditional religious belief had been proscribed as objects of public veneration or celebration, the whole concept of the hero or heroine as a model for appropriate behaviour had largely to be rethought. Especially in the Elizabethan years part of that rethinking had of course to do with the search for suitable images of female as opposed to male authority. The images of the warrior king, or David battling Goliath, which had been employed as appropriate to the reign of Henry vIII, ${ }^{3}$ yielded under Elizabeth to those of Deborah, Astraea, Belphoebe and Tuccia 
the Virgin. ${ }^{4}$ Another part of that rethinking had to do with the recognition of secular and indeed urban figures, including important civic officials and benefactors. These now came to the fore as the objects of celebration in place of such pre-Reformation counterparts as, for example, biblical figures, saints, and prominent donors of pious bequests. In the hands of writers like Heywood they came to be seen as morally worthy figures rather than the greedy, avaricious and sinister stereotypes which had long been, and were often still, commonly applied to denizens of the urban scene. ${ }^{5}$

Some of these secular figures such as Dick Whittington (c. 1350-1423) or Lady Godiva (d. c. 1067) ${ }^{7}$ were long-deceased and were now substantially revived in the public memory. Others such as Sir Thomas Gresham (1518-79), himself a central figure in Heywood's play, or that benefactor extraordinaire Sir Thomas White (d. 1567) made their careers in the post-reformation era. Never having faded far from view, their memories had merely to be sustained and perhaps embellished. ${ }^{8}$ Heywood's use of Alexander Nowell (c. 1516-1602), a well-known London figure as Dean of St Paul's and one of the leading intellectuals of the day, itself provides another good example of this lionization of an urban leader.

Heywood also touches on a vivid contemporary concern in singling out figures celebrated for their charitable benefactions, his 'charitable citizens', so that in reflecting upon them, his guests might 'refresh' their 'owne soules' (C4). One of the most common contemporary criticisms made of urban society in England during this era concerned the perceived growing neglect of charitable acts. ${ }^{9}$ There may well be some degree of irony here, as modern scholarly treatments of the subject have not always substantiated that perception. ${ }^{10}$ But however erroneous it may have been, the contemporary impression of a decline in charitable giving cannot be denied. It stemmed in part from the destruction of both the traditional rationale for charitable giving as a means to salvation and also from the ensuing destruction of hundreds upon hundreds of those ecclesiastical and lay institutions which had emerged to encourage and facilitate such philanthropy in the form of pious bequests. It stemmed too from the difficult economic and social conditions of the era, especially of the $1550 \mathrm{~s}^{11}$ and (in Heywood's own impressionable young adulthood) the $1590 \mathrm{~s},{ }^{12}$ by all accounts the two most crisis-ridden decades of the century. The well known commentaries on the decline of charitable giving by John Stow in his 1597 Survey of London ${ }^{13}$ merely expressed in nostalgic terms the contemporary perceptions to which Queen and parliament responded in the climactic Elizabethan poor laws of 1597 and 1601. ${ }^{14}$ 
Writing his play with the peak of these difficulties fresh in mind, presumably in those very months preceding the Midland Peasant Rising of 1607 , Heywood's exemplification of charitable citizens as models to be emulated by others served as a heartfelt and timely expression. His vignette of Nowell in his picture gallery is in these respects clearly a polemical scene in a polemical play. In championing the social role of the citizen, and thus reversing a largely negative reputation long attached to the urban milieu, we may place it along with writings by contemporaries like Thomas Churchyard, William Harrison, Sir Thomas Smith, and William Camden. ${ }^{15}$ But Heywood's play stands out even amongst that distinguished company in recognizing the particular virtue of civic benefaction, and in exemplifying the role of women as well as men therein. Additionally significant is that such female benefactors were not all of royal or aristocratic status; their contemporaries encouraged women as well as men to 'refresh your soules' by contemplating role models of both sexes for such activity. These were important reminders in Heywood's time. With the dissolution of myriad hospitals, confraternities and other institutions which had traditionally facilitated the charitable roles of women, and which continued to do so in Catholic countries, the opportunities for female beneficence had declined in England, and the proportion of charitable bequests attributed to women followed suit. ${ }^{16}$ Some contemporaries even cast aspersions on some forms of female benefactions, and on the women who made them. ${ }^{17}$

Although Heywood obviously used the stage as his preferred pulpit, this scene shows his recognition that portraiture could also be an effective celebratory medium by that time, and that by implication it had attracted a sufficiently large 'public' so as to be able to perform that function. The point of the scene, after all, was not to show that Nowell had portraits of his friends on his walls, for such had been a sufficiently common practice for quite some time and was by 1606 entirely unworthy of remark. ${ }^{18}$ Nor was it especially meant to demonstrate the ownership and use of portraiture as a common means of self-fashioning, for this had also become a commonplace. The point seems rather to be the use of portraits to celebrate the civic virtue of charity, amongst women as well as men, and to inculcate that virtue upon that other well-established public of theatre-goers (women as well as men) who would have seen his play. Heywood's inclusion of Gibson's and Foster's images shows that female benefactors could well be, and certainly were, portrayed on panel or canvas as mementos of those benefactions, and that such portraits could enshrine them no less than their male counterparts in the civic memory. We 
may read Lady Mary Ramsey's reaction to Nowell's portraits of Gibson and Foster as Heywood's own, and as essential to the meaning of the scene.

Those points seem important to make not only in Heywood's time but also in our own, especially as we seek a fuller understanding, first, of the role of women in English society of that time, and second, of the use of portraiture as a form of civic discourse, intended to encourage particular civic virtues and to do so especially amongst the urban-centred and middling sorts of people. Then, too, the subject of female benefaction, as opposed, for example, to female recipients of charity, has not been much recognized in modern scholarship. ${ }^{19}$ Yet given sufficient means, and despite what were sometimes different philosophical or religious motivations, and though they did so to a declining degree, women directly supported such institutions as schools and hospitals after as well as before the reformation.

Undeniably, women's benefactions often came in fulfilment of a deceased husband's wishes, or in commemoration of his life, or in furthering causes, whether in his lifetime or after, which he deemed important. Heywood's Agnes Foster and Anne Gibson, both wives of altruistic lord mayors, certainly fit this description and, judging by John Stow's reportage, were well known to have done so in their time. ${ }^{20}$ But women were also capable of acting on their own. Many others did just that, and for the same religious, moral, philosophical, social, and even political reasons which applied to men. Some even worked in direct contravention of their husband's wishes, and were celebrated in Heywood's time for so doing. The only semi-mythical Lady Godiva of Coventry, who publicly defied her husband's autocratic inclinations towards his subjects in the eleventh century, was recalled and celebrated anew in an intriguing civic portrait of 1586 in that City. ${ }^{21}$ To note that women often engaged in charity at their husband's wishes or in their honour is merely to recognize the reality that wealthy women of the era at hand were more likely than not to have derived their wealth and/or influence from their husbands, whether living or, especially, deceased.

And as for portraiture itself, its function in observing the lives and contributions of the middling elites, including citizens of London and other urban centres, as opposed to royalty and the landed classes, has also been vastly under-explored. Heywood is of course writing a work of fiction, and we cannot necessarily assume that the particular portraits he had Nowell show off in his gallery actually ever existed. But they may well have done so. Certainly Heywood did not consider such a prospect unusual or unlikely. More to the point, Stow tells us that a portrait of Anne Gibson once hung in the chapel of 
the Ratcliffe School which she had endowed, but was taken down when the Coopers took the school over from the Grocers. ${ }^{22}$ In any event, and in ironic contrast to the surviving portrait of Lady Mary Ramsey discussed below, if Nowell's portraits did exist, they do not seem to have survived to the present. But their existence in precisely the space and context in which Heywood placed them in this play remains entirely plausible for the time, and Nowell's guests certainly reacted to them in that light.

Leaving aside the benefactions of reigning queens, to whom all sorts of other considerations applied, surviving portraits of three female benefactors who were portrayed on panel around the time of Heywood's play demonstrate the point at hand. He was indeed describing a plausable scene. They are Joan Cooke of Gloucester (d. 1544), Joyce Frankland of London (1531-87), and that very same Lady Mary Ramsey (d. 1601) whom Heywood very likely had known personally. All three of them were urban figures, performing their benefactions to establish or sustain urban institutions. Cooke was essentially a pre-reformation figure, wedded to the old faith and making her signal benefactions on the virtual eve of the dissolutions, but she was celebrated, posthumously, as an institutional benefactor only some two generations later. Ramsey and Frankland lived on into Heywood's own time (c. 1573-1641). All three were commemorated in panel portraits of that era, and their images did indeed serve the commemorative function of panel portraiture as he observed it. Many more portraits of female benefactors of that era have survived to the present, ${ }^{23}$ but even this small sampling reveals the social range of women who made them, the circumstances surrounding their benefactions, and the use of the portrait medium as Heywood knew it, to commemorate both benefactors and their benefactions.

One could of course also point to female benefactors of a much more elevated status who were also portrayed in this era. Lady Margaret Beaufort, for one, endowed several professorships in divinity at Cambridge, transformed the earlier and impoverished foundation of God's House at the same University into the renamed Christ's College with an endowment of $£ 5000$ in 1505-6, supported St John's College even more lavishly, ${ }^{24}$ and encouraged prominent members of her own entourage to nurture these and other Cambridge colleges. ${ }^{25}$ With contributions to myriad other causes and institutions as well, the total of her benefactions exceeded the astonishing sum of $£ 18,000 .{ }^{26}$ She was one of the first female benefactors to be portrayed in that light on panel, being first portrayed in the second decade of the sixteenth century. But it is also significant that she was portrayed again towards 
the end of the century, in Heywood's life-time, and in those very years when such civic portraiture flourished to fill the void in the ranks of heroic exemplars. ${ }^{27}$ But in excluding such truly elite figures as these from his picture gallery, Heywood indicated greater interest in women of a distinctly middling, urban background. Well might he have done so, for of course not all the female benefactors portrayed in his time shared the elevated social status of a Margaret Beaufort.

Joan (Messenger) Cooke emerged from quite a different quadrant of the social spectrum, and the double portrait of Joan and her husband John marks a further stage in the commemorative use of portraiture. A native of Gloucester, Joan died around 1544, some sixteen years after her husband John, a wealthy brewer and mercer of that city. Joan Cooke's benefactions, unlike the other two women's, were closely related to her spouse's charitable interests, a fact commemorated by the unique double portrait in which their images survive. [Fig. 1] Coming up through the familiar cursus honorum of city and guild organizations in the 1480s, John Cooke served twice as sheriff of Gloucester in the 1490s, and as mayor four times between 1501 and 1518 . He was obviously one of the most dominant figures in Gloucester's affairs in the several decades following that city's incorporation as a county in and of itself in $1483 .{ }^{28}$ His will tells us that in addition to pious bequests to local churches and for the care of his soul, and bequests of his lands and tenements to his wife, Joan, he gave widely to civic causes. He supported the poor of St Bartholomew's Hospital and the repair of the great West Bridge of the city and of two of its main roads, ${ }^{29}$ and he endowed the foundation of a free grammar school in the parish of St Mary de Crypt for the 'erudition' of its children. ${ }^{30}$ To see that these bequests were carried out John named Joan as his sole executor. He entrusted her brother, Alderman Thomas Messenger, and several other prominent townsmen with the foundation of the school. This came to be known as the Crypt School because of its location adjacent to St Mary de Crypt Church in Southgate Street.

Joan herself never remarried. She spent her remaining years, as the lengthy inscription along the bottom of the panel tells us, performing ye taske Her Husband did intend'. She purchased much of the lands of the former Llanthony Priory after it was dissolved, and used the site, adjacent to St Mary de Crypt, to build the intended school. It was completed by 1539 . By her own will of May, 1544, she too left sums to the church and for pious bequests, and she too left money to keep up one of the main roads out of Gloucester. She also endowed the Cathedral Church of St Peter's and its high altar, and also a 


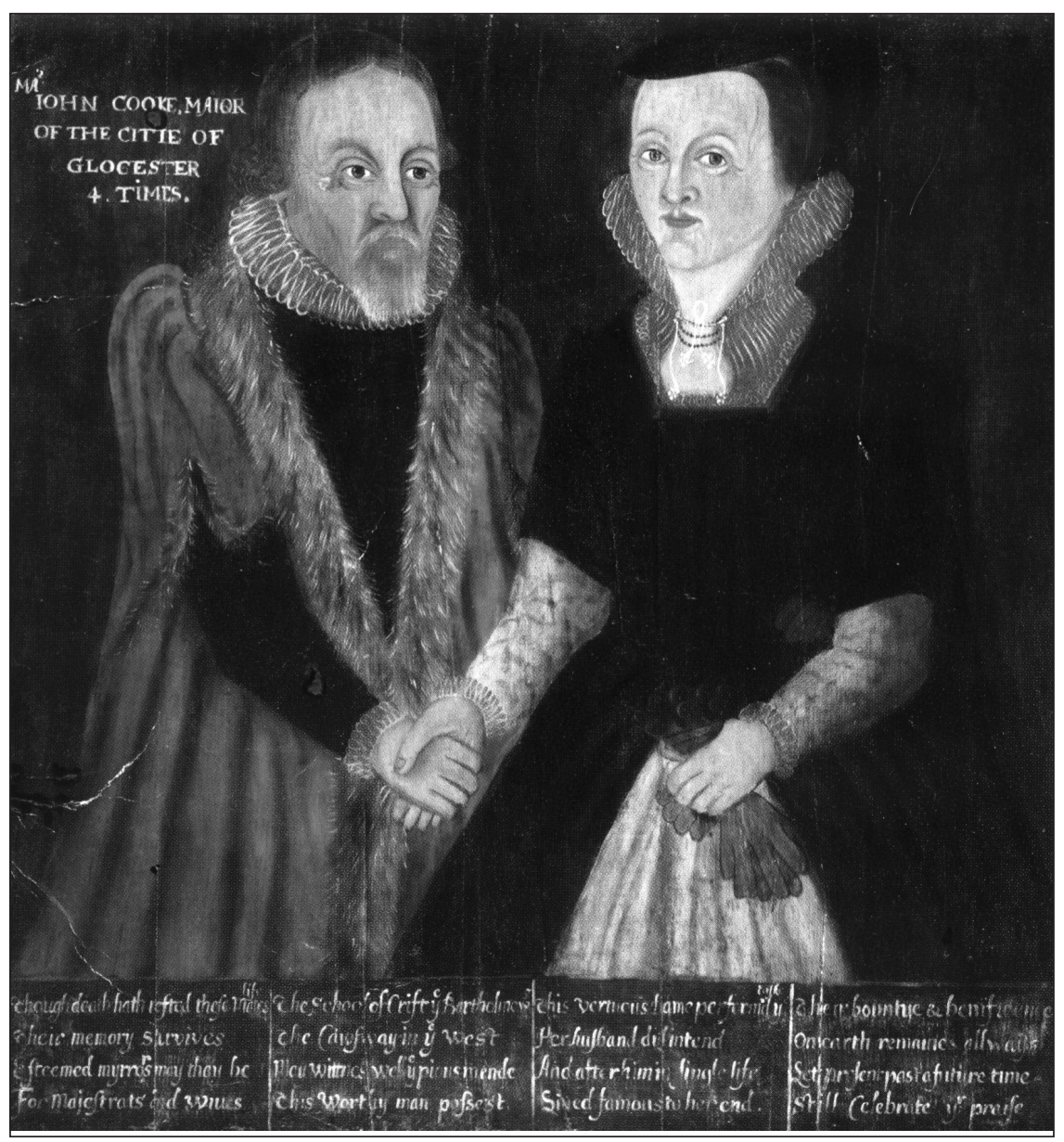

Fig. 1. 'John and Joan Cooke', Co. Gloucester City Museum \& Art Gallery.

perpetual chantry to be governed by a board of feoffees. It was probably one of the last chantries to be founded anywhere in England before the dissolution of such institutions which began shortly thereafter. Joan rounded out her bequests by remembering the inmates of three local hospitals and the poor prisoners in the city's gaols. ${ }^{31}$ Neither will mentions children, suggesting either that the couple remained childless or that their children pre-deceased them.

The painting, an anonymous vernacular composition, was almost certainly done between c. 1597 and 1629 as part of a series of portraits of Gloucester benefactors of that era. As a double rather than single portrait, and as 
one with considerable and unusual iconographic elements, it begs a little fuller description than most. Such a close look shows the relationship between the two, and their relationship to the benefactions, both ingeniously and clearly. ${ }^{32}$ Against the merest suggestion of a dark brown drapery, we see John Cooke, in his scarlet mayoral robe trimmed with fur, standing rigidly on our left. He seems to be staring blankly, indeed almost catatonically, off into the distance beyond our right shoulder. His wife Joan, on his left, clasps his right hand in hers, and she draws it leftwards across his body as if to lead him (or, metaphorically, his will) forward. Her right hand clutches a pair of brown leather gloves, a conventional symbol in contemporary merchants' portraits of membership in the freemanry, a status which, as this symbolism suggests, she would have inherited from John. ${ }^{33}$

Unlike the comatose appearance of her husband, Joan stares right at the viewer and strikes a pose as the dominant figure: she looks younger, brighteyed and more alert than John, she stands slightly in front of him, and she alone makes eye contact with us. Her side of the painting, on our right, seems better lit, as if the painter wished to place the emphasis on her rather than on him. A brief inscription in the upper left-hand corner, next to John's head, tells us that he is 'MAster Iohn Cooke, Maior of the Citie of Glocester 4 Times'. A much longer inscription, in the form of a poem, runs along the bottom few inches of the portrait. It reads as follows:

Though death hath rested these life mates

Their memory survives

Esteemed myrrors may they be

For Majestrats and wives

The School of Crist ye Bartholomews

The Cawseway in ye West

May wittnes wch ye pious minde

This Worthy man possest.

This vertuous dame perform'd ye taske

Her husband did intend

And after him in single life

Lived famous to her end

Their bountye $\&$ benificence

On earth remaines allways

Let present past and future time

Still Celebrate yr praise. 
The Cookes' wills, traditionally Roman Catholic in their testamentary formulae, show that both John and Joan were obviously concerned with the salvation of their souls through the performance of good works. ${ }^{34}$ The fact that they commissioned a funerary brass for their parish church further attests to their piety. ${ }^{35}$ But, unlike many of their contemporaries, their support for the causeway to the west of the city and their foundation of the Crypt School show them equally concerned with benefactions of a civic and secular nature. Jordan's seminal study of charitable patterns before and after the Reformation emphasizes the small proportion of pre-reformation bequests which went to civic betterment via secular institutions. ${ }^{36}$ The Cookes' portrait nevertheless supports the notion of a highly developed 'civic Catholicism' at work prior to the reformation, if not perhaps amongst the majority of benefactors, then at least amongst some of the more enlightened and well-placed. By the time the painting seems to have been completed, many people thought that the spirit of civic beneficence had waned, thus making the importance of stressing such beneficence greater than ever. That factor, emphasized time and time again by Stow, accounts in this and many other posthumous portraits for the considerable time-lag between the Cookes' lives and the portrait depicting them. ${ }^{37}$

In contrast to the funerary brass of the Cookes placed in the parish church after (or perhaps, as was not an entirely unknown practice, even before) their deaths, ${ }^{38}$ the painting seems to have been intended for the school which they founded and not for an ecclesiastical setting at all. It would have served there as a reminder to the pupils of that institution the importance of good citizenship, and perhaps to the masters as a model of civic virtue which it was their task to impress upon those pupils and to exemplify by their own leadership. In both respects it served as an early example of the type of founder' portraits, of women as well as men, which soon appeared elsewhere, in such schools as Christ's Hospital, now in Horsham, ${ }^{39}$ its namesake in Abingdon, ${ }^{40}$ and numerous other institutions. ${ }^{41}$

Active a half century after Joan Cooke's benefactions in Gloucester and at roughly the same time as the Cookes were being celebrated in portraiture for that act, Lady Mary Ramsey herself embarked with her husband on a huge programme of philanthropic works, mostly in and around London. W.K. Jordan reckoned that, taken together, they spent the enormous sum of $£ 14,317$ over some two decades on various schemes, the most widely known of which were probably the endowments made in 1583 to sustain Christ's Hospital in London and an endowment of $£ 1000$ to Queen Elizabeth's Hospital in Bristol. Though Sir Thomas, who served as lord mayor of London in $1577-8$ and 
as president of Christ's from 1582 to his death in $1590,{ }^{42}$ may have charted the course of this philanthropic activity of the 1580s, Lady Mary continued his work for a decade after his death until her own in 1601, giving lavishly of her own inheritance: to Christ's Hospital, the foundation of an Essex grammar school, to the poor of London parishes, to several City companies, to the borough of Bristol, and to stocks for the relieve of debtors, wounded soldiers, and university students. ${ }^{43}$ Why indeed, as her character asks in Heywood's play, should she not be remembered for it?

Christ's Hospital was one of five hospitals, along with St Bartholomew's, St. Thomas's, Bethlem, and Bridewell, whch were re-founded in response to the alarming social and economic conditions of the mid-sixteenth century in London. They seem to have emanated not from the pious motives exemplified by Lady Margaret Beaufort or even Joan Cooke, but rather from the same humanist-inspired thinking and from the contemporary circle of progressive London leaders of their time. By the end of the century and taken together, they were providing support in some form or other to some 4,000 indigents a year, a collaborative effort which ranked with the largest charitable institutions on the continent. And in contrast to most such institutions, they were governed by trustees appointed by the London City government and independent of the parish: the operating scale simply being too large for the traditional parish-based administrative structure. Christ's itself opened to receive foundling children in 1552 , an event commemorated in a huge painting of Edward vi presenting its charter which is still displayed in the current school's dining hall. Mary Tudor confirmed that charter a few years later, and the institution continued to flourish thereafter, becoming one of the largest and most fashionably supported institutions of its time. ${ }^{44}$ Its presidents were conventionally former lord mayors of London.

Like Lady Margaret Beaufort's, Lady Mary Ramsey's portrait (presumably commissioned by the Hospital not too long after her death) also has its subject holding a book, but the resemblance goes little further. [fig. 2] Ramsey holds her book in her right hand in a gesture intended to attest to her literacy and her appreciation of reading. ${ }^{45}$ But the extravagant, open-handed, declamatory gesture made by her left hand suggests nothing like a prayer book (though it might be a bible or a book of sermons), or the performance of a devotional act. In the setting of the hospital, essentially a school whose principal function even then was to educate orphans or the children of the destitute, this gesture attested to her commitment to learning, and her bene- 
faction towards that end: striking contemporary affirmations of a woman's altruistic and intellectual potential.

Joyce Frankland's wealth derived from the legacies of her two husbands, both London Clothworkers, and possibly from her father, a London Goldsmith. By 1577 she had been widowed a second time, and had only her son, William, remaining. When he was thrown from a horse and tragically killed in 1581 she is said to have been beside herself with grief. According to that story, the very same Alexander Nowell whom Heywood chose to host the gathering noted above and an obviously close friend to Frankland, rushed to her side and suggested that she could extend her largesse to other young men of her son's approximate age by making endowments to university colleges. Whether this tradition (which does have plausibility if not firm evidence on its side) holds water or not, Joyce did proceed to follow that course, endowing Gonville and Caius College, Cambridge, with a chaplaincy, six fellowships and other benefactions to the cost of $£ 2080$; Emmanuel College, Cambridge, with fellowships and scholarships at $£ 400$; Brasenose College,

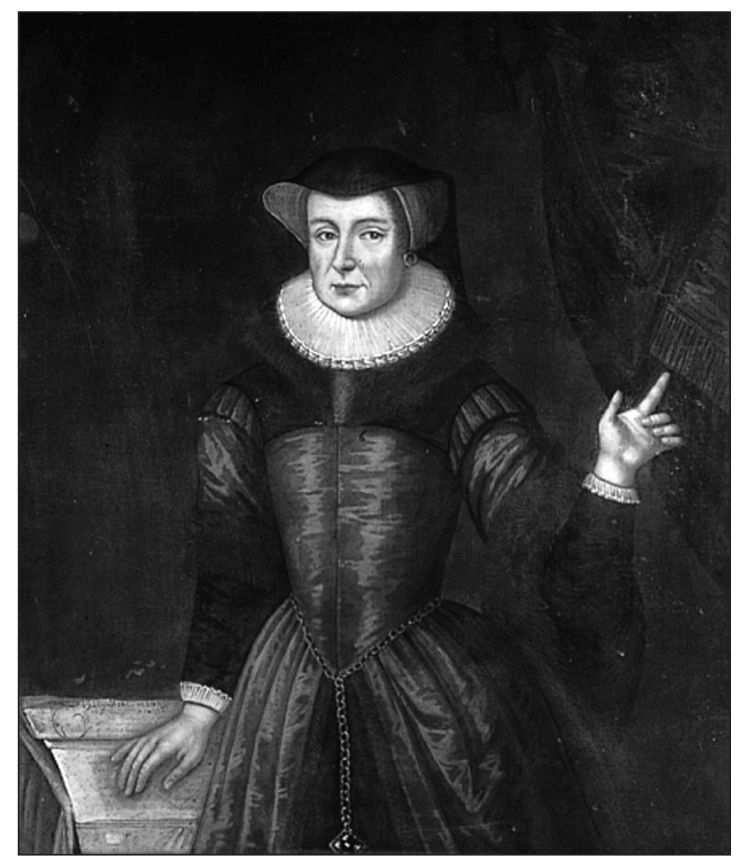

Fig. 2. 'Lady Mary Ramsay', by kind prmission of Christ's Hospital, Horsham, England, a charitable school founded in 1552. Website: <www.christ's-hospital.org.uk> 
Oxford (to which Nowell was also a generous benefactor) with capital, plate and scholarships worth over $£ 2000$, and the Grammar School of Newport, Essex, with $£ 470.46$ These were enormous endowments for their time and, as Frankland herself was very well aware, they merited recognition in portrait form. Somewhat unusually for what we may call 'civic portraits', most of which were commissioned by institutions, she determined that portraits of herself be commissioned and given to Gonville and Caius, Emmanuel, and to both Brasenose and Lincoln College, Oxford. The latter had been endowed by her wealthy mother rather than herself. Portraits of her parents were to be set up at Brasenose as well. ${ }^{47}$

In fact, the Lincoln portrait seem not to have been carried out, but three more, housed at Brasenose, appear to have been modeled on the Gonville and Caius work of 1586 and to have been dated to the waning years of the sixteenth century. The third has been attributed to Gilbert Jackson, an active painter in London and Oxford, and dated 1638. [fig. 3] The earliest of the lot bore only her coat of arms and her motto, 'suffer and service', in addition

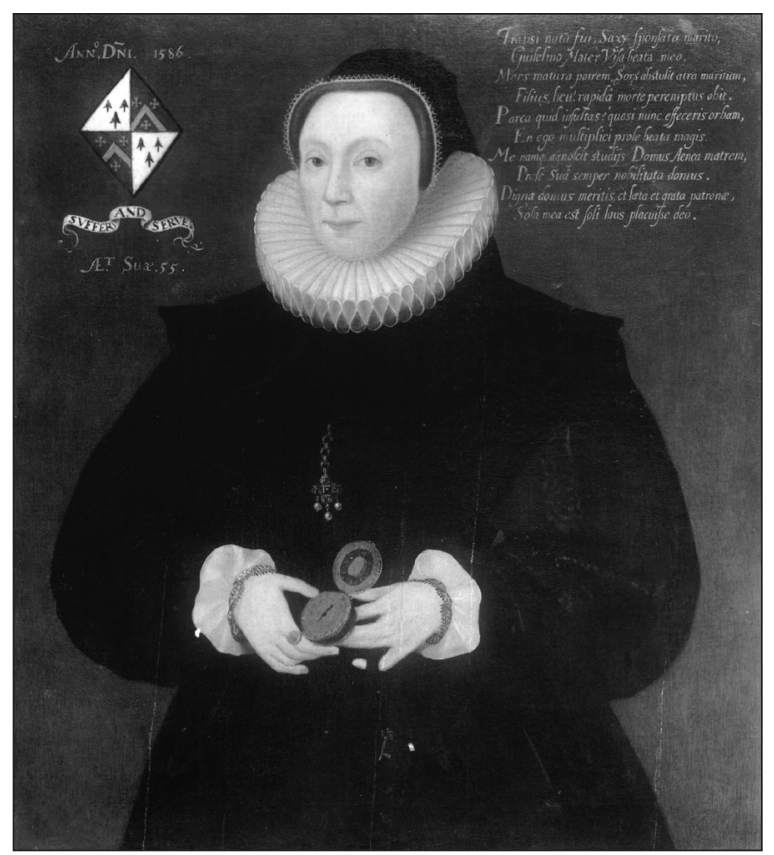

Fig. 3. 'Joyce Frankland', with thanks to the Principal and Fellows of Brasenose College. Oxford'. 
to the figure itself, but inscriptions, verses (those on one of the Brasenose portraits allegedly by Nowell) and dates appear on later versions. The smaller Brasenose portrait, inscribed with the date 1586 and her age, fifty-five, seems a slightly later painting which added this information for reference. ${ }^{48}$ As the Caius prototype appeared a year before Joyce's death in 1601, we can assume it to be an accurate likeness, though accuracy was not necessarily the case with civic portraits. As with John and Joan Cooke, many portraits were commissioned so long after the subject's death as to make such verisimilitude impossible, though this fact mattered little to contemporaries bent on commemoration rather than literal depiction.

Frankland's portraits are as striking and distinctive in their own way as the others under the lens here, and they suggest some equally striking characteristics of their subject. She is shown in all of these portraits in a dark gown fitted at the waist, with a head-dress, ruffed collar, and a fashionable pendant hanging from a short chain protruding from the seam of her gown. But the most distinctive element is the watch or small clock which Joan holds in both hands, open-faced, at the level of her waist. Reasonably enough for a women of fifty-five in that era, it signals her preoccupation with the fact of mortality (a vivid recognition for one who had lost two husbands and a young son), of time's inexorable movement through life's course, and perhaps of the importance of making benefactions whilst one could. But it also shows a women possessing an intricate and still somewhat uncommon mechanical device and thus fully (if not ostentatiously) engaged with the cultural and material fashions of her age.

A final point regarding Frankland lies in the fact that she alone of the trio of female benefactors made provisions for her own portrait rather than waiting for posterity to do so for her. This planning suggests that a sitter's personal motives in such commemoration did not entirely vanish with the reformation's proscription of pious bequests. Frankland may or may not have thought of this benefaction in such traditional light, but she certainly maintained an interest in perpetuating her memory, and that of her parents, amongst the institutional beneficiaries of her bequest. In that aim she was not alone amongst pre-reformation benefactors of either gender. ${ }^{49}$

Some of the uses of portraiture in post-reformation England are well known to us. Monarchs used them to convey images of power, wisdom, and authority; ${ }^{50}$ landed elites used them in the pursuit of self-fashioning or in the fash- 
ion of collecting and display; ${ }^{51}$ some people like the musician Thomas Whythorne used them as records of personal appearance through the years, so that they could tell how they had aged and could leave mementos of their appearance to their descendants. ${ }^{52}$ And civic institutions commissioned portraits of their founders, officers and benefactors as talismans of civic virtue. ${ }^{53}$ But some of its uses have pretty much faded from our view.

We may now affirm that Heywood's presentation of female as well as male benefactors as subjects for portraiture draws from fact rather than fancy, and his audience would have recognized it as such. The middling status and urban nature of Heywood's figures affirm that female benefactors spanned a fairly wide social spectrum and successfully bridged the theological and chronological divide represented by the reformation. What was once given as a pious bequest in response to what we might call the 'purgatorial imperative' prior to the reformation now became, and was encouraged to become, a secular benefaction to the civic community. Both Nowell's portraits in Heywood's play, and other female sitters of the era suggest that female benefactors had a particular interest in fostering education, especially for the disadvantaged: another element which appears to have spanned the reformation years. Furthermore, in the course of that portrait record, women were also portrayed as literate and sophisticated people. Almost all such actual works indicate an engagement with the written word by their display of books or scrolls, and with similarly progressive elements of material culture, time-pieces included. Heywood's play adds weight to what we are able to assemble from other portrait evidence, and makes a pointed statement about the potential for female contributions to the society of his time.

\section{Notes}

My thanks to Dr Claire Schen, Dr Joseph P. Ward, and the two anonymous outside readers for this journal for their suggestions on this paper, though none of them should be held accountable for its remaining infelicities.

1 Ian Archer, 'The Arts and Acts of Memorialization in Early Modern London', Imagining Early Modern London, Perceptions and Portrayals of the City from Stow to Strype, 1598-1720, J.F. Merritt (ed) (Cambridge, 2001), 89-90; and Archer, 'The Charity of London Widows in Late Sixteenth and Early Seventeenth Centuries' Local Identities in Late Medieval and Early Modern England, Norman L. Jones and Daniel Woolf (eds) (Basingstoke, 2007), 178-80. 
2 Thomas Heywood, If You Know Not Me, You Know No Body (London, 1623), stc $2^{\text {nd }}$ ed. 13338 (Harvard copy). Stow lavishes praise on Foster and Gibson, amongst other London women, for their benefactions; John Stow, A Survey of London by John Stow, reprinted from the text of 1603, Charles L. Kingsford (ed.), 2 vols (Oxford, 1908), 1.116, hereafter cited as Stow, Survey.

3 See especially Christopher Lloyd and Simon Thurley, Henry VIII, Images of a Tudor King (London, 1990), 29-30.

4 See for example, Andrew Belsey and Catherine Belsey, 'Icons of Divinity, Portraits of Elizabeth I', Renaissance Bodies, Lucy Gent and Nigel Llewellyn (eds) (London, 1990), 11-35; Susan Doran, 'Virginity, Divinity and Power, the Portraits of Elizabeth I', The Myth of Elizabeth I, Susan Doran and Thomas S. Freeman (eds) (Basingstoke, 2003); Helen Hackett, Virgin Mother, Maiden: Queen Elizabeth I and the Cult of the Virgin Mary (London, 1995); John N. King, 'The Godly Woman in Elizabethan Iconography', Renaissance Quarterly 38 (1985), 41-84 and 'Queen Elizabeth I, Representations of the Virgin Queen', Renaissance Quarterly 43 (1990), 30-74; Louis Montrose, 'Idols of the Queen: Gender and the Picturing of Elizabeth I', Representations 68 (1999), 108-48; Elizabeth Pomeroy, Reading the Portraits of Queen Elizabeth (Hamden, Ct., 1989); Frances Yates, 'Queen Elizabeth as "Astraea”, Jl. Courtauld and Warburg Institutes 10 (1947), 27-82.

5 See, for example, Laura Stevenson O'Connell, 'Anti-Entrepreneurial Attitudes in Elizabethan Sermons and Popular Literature', Journal of British Studies 15 (1976), 2-20; Lawrence Manley, Literature and Culture in Early Modern London (Cambridge, 1995), 113-7.

6 Heywood's inclusion of Whittington's portrait in Nowell's picture gallery is but one indication of the growing popularity of this early-fifteenth century figure in postreformation media; Renold Elstrack's popular engraving of Whittington speaks to the same effect. See C.M. Barron, 'Richard Whittington: the Man Behind the Myth', Studies in London History Presented to Philip Edmund Jones, A.E J. Hollaender and W. Kellaway (eds) (London, 1969), 197-248; Arthur M. Hind, Engraving in England in the Sixteenth and Seventeenth Centuries, 3 vols (Cambridge, 1952-1964) 2.192-3; Oxford Dictionary of National Biography [hereafter ODNB] vide Whittington, Sir Richard.

7 The portrait of her now in the Herbert Art Gallery and Museum in Coventry, dated to 1586 , is but one indication of her celebration in these same years; Ron Aquilla Clarke and Patricia A.E. Day, Lady Godiva, Images of a Legend in Art and Society (Coventry, 1982), passim.

8 Both were born before the Reformation, but achieved their fame and fortune thereafter. S.T. Bindoff, 'The Fame of Sir Thomas Gresham' (Neale Lecture in English 
History, London,1973); Robert Tittler, 'Sir Thomas White of London: Civic Philanthropy and the Making of the Merchant Hero', Townspeople and Nation, English Urban Experiences, 1540-1640, Robert Tittler (Stanford, 2001), 100-20.

9 Paul Slack, Poverty and Policy in Tudor and Stuart England (London, 1988), 19-21, 164, 167; Ian Archer, 'The Charity of Early Modern Londoners', Transactions of the Royal Historical Society 12 (2002), 226-7, citing works by Thomas Nashe and sermons by Lawrence Chadderton (1578), Nathaniel Shute (1626), Thomas Drant (1570), Henry Smith (1592), William Cupper (1592), Stephen Denison (1619), Andrew Willet (1603), Adam Hill (1595) and Daniel Price (1617).

10 Both Susan Brigden and Ian Archer have affirmed an increase in charitable giving in general from the mid-century mark, but Archer has also found a decline in such giving amongst women. Susan Brigden, 'Religion and Social Obligation in Early Sixteenth Century London', Past and Present 103 (May, 1984), especially 103-5; Ian Archer, The Pursuit of Stability, Social Relations in Early Modern London (Cambridge, 1991), 163-82, but see also Archer, 'The Charity of Early Modern Londoners', Table I, 230.

11 On the former, see Whitney R.D. Jones, The Mid-Tudor Crisis 1539-1563 (Basingstoke,1973) which stated the nature of the crisis in the baldest terms; followed by Jennifer Loach and Robert Tittler (eds) The Mid-Tudor Polity, c. 1540-1560 (Basingstoke,1980) and David Loades, The Mid-Tudor Crisis, 1545-1565 (London, 1992) which explored the issues in perhaps subtler terms and qualified that aspect of the perceived 'crisis' which had concerned the efficacy of governing bodies in meeting it.

12 See S.T. Bindoff, Tudor England (London, 1950) chapter 9; Andrew B. Appleby, Famine in Tudor and Stuart England (Stanford, 1978); Peter Clark, The European Crisis of the 1590s, Essays in Comparative History (London, 1985); Paul Slack, Poverty and Policy in Tudor and Stuart England (1988), 48-52; John Guy (ed.) The Reign of Elizabeth I: Court and Culture in the Last Decade, (Cambridge, 1995), Introduction and chapter 9; and David Dean, Law-Making and Society in Late Elizabethan England, the Parliaments of England, 1584-1601 (Cambridge, 1996), especially 168-77.

13 Stow, Survey, especially I: 85-91 et passim and, in general, Ian Archer, 'The Nostalgia of John Stow', The Theatrical City; Culture, Theatre and Politics in London, 1576-1649, in D. L. Smith, Richard Strier and David Bevington (eds) (Cambridge, 1995), 17-34.

1439 Eliz. c. 3 and 43 Eliz., c. 2.

15 J.P. Cooper, 'Ideals of Gentility in Early Modern England' Land, Men and Beliefs: Studies in Early Modern History, J.P. Cooper; G.E. Aylmer and J.S. Morrill (eds) (London, 1983), 59, 65-6; Laura Caroline Stevenson, Praise and Paradox: Merchants and Craftsmen in Elizabethan Popular Literature (Cambridge, 1984), 79-81; Manley, Literature and Culture in Early Modern London, passim. 
16 Claire S. Schen, Charity and Lay Piety in Reformation London, 1500-1620 (Aldershot, Hants., 2002), 141-5; Archer, 'Charity of Early Modern Londoners', 230, Table I.

17 Schen, 'Charity and Lay Piety', 246-7.

18 Thomas Whythorne displayed on the wall of what must, at that early stage of his life, have been a very modest dwelling a picture of a widow with whom he was enamored around 1553. Susan Foister's pathbreaking study of portraits in household inventories affirms that this was reasonably common practice well before Heywood wrote. Thomas Whythorne, The Autobiography of Thomas Whythorne, James M. Osborne (ed) (Oxford, 1961), 48; Susan Foister, 'Paintings and Other Works of Art in Sixteenth Century English Inventories', The Burlington Magazine 123 (May, 1981), 273-82.

19 W.K. Jordan, The Charities of London, 1480-1660 (London, 1960), 28-32; Jordan, Philanthropy in England, 1480-1660 (London, 1959), 221-4, 227-8, 353-5, 382-3, and passing reference to individual female benefactors in the same author's The Charities of Rural England, 1480-1660 (London, 1961). Even briefer, if more recent, discussions may be found in Schen, Charity and Lay Piety in Reformation London, 8-10 and 241-5; Sara Mendelson and Patricia Crawford, Women in Early Modern England, (Oxford, 1998), 181-2; Vivien Brodsky, 'Widows in Late Elizabethan London: Remarriage, Economic Opportunity and Family Orientations', Lloyd Bonfield, Richard M. Smith and Keith Wrightson (eds), The World We Have Gained, Histories of Population and Social Structure, (Oxford, 1986), 150-1.

20 Stow, Survey, 1.116-7.

$21 O D N B$, vide, Godiva and n.3 above.

22 Stow, Survey, 1.116.

23 Excluding royalty, thirty-one surviving portraits of female benefactors have been identified so far in the period 1500-1640. See Robert Tittler, The Face of the City: Civic Portraits and Civic Identity in Early Modern England (Manchester, 2007), Appendix A, 169-86.

24 Jordan lists this as an initial outlay of $£ 5000$ for the fabric of the building, and then an additional $£ 8000$ worth of income from lands for working capital; Jordan, Charities of London, 261.

$25 O D N B$, vide Beaufort, Lady Margaret.

26 Jordan, Charities of London, 30.

27 The executors of her will commissioned the fashionable court painter Maynard Vewicke to do a portrait of her for Christ's itself just after her death in 1511. Completed before 1513 and no longer extant, it may well have served as a model for one done in the 1580s, owned by and probably commissioned by the same College. And finally, Rowland Lockey's portrait of Margaret of about 1598 seems to have been commissioned by, and was presented to, St John's College at that time. Roy Strong, 
Tudor and Jacobean Portraits, 2 vols (London, 1969) 1.20; John Fletcher, 'Tree Ring Dates for Some Panel Paintings in England', Burlington Magazine 116 (May, 1974), 255-6; Pamela Tudor-Craig, Richard III (National Portrait Gallery Exhibition Catalogue, $2^{\text {nd }}$ ed. ., London, 1977), 91; J.W. Goodison, Catalogue of Cambridge Portraits, 2 vols (Cambridge, 1955), 1.xvii; J.W. Goodison (ed.), Catalogue of the Portraits in Christ's, Clare and Sidney Sussex Colleges (Cambridge, 1985), 35-6; Frederick Hepburn, 'The Portraiture of Lady Margaret Beaufort', The Antiquaries Journal 72 (1992), 118-40; Janet Backhouse, 'Lady Margaret Beaufort', Gothic Art for England, Robert Marks and Paul Williamson (eds) (London, 2003), 246-9; Susan Foister, Holbein and England, (London and New Haven, 2004), 16, 19-20.

28 Martin Weinbaum, British Borough Charters, 1307-1660 (Cambridge, 1943), xxxviii.

29 M.D. Lobel (ed.) Historic Towns (Baltimore, nd), 14 ff.

30 National Archives [hereafter NA], ргов 11/22/38.

31 NA, рRов 11/31/4.

32 The dating must remain inexact for lack of specific evidence. The city accounts in which the payment for this work should have been recorded do not bear such a record prior to 1597, the point at which they cease to exist for over three decades. The couple's dress further suggests this dating range. I am grateful to Dr Susan North of the Victoria and Albert Museum, and Dr Tarnya Cooper of the National Portrait Gallery, for their thoughts on costume and dating.

33 Robert Tittler, 'Freemen's Gloves and Civic Authority: the Evidence from Post-Reformation Portraiture', Costume 40 (2006), 13-20.

34 NA, ргов 11/22/38 (John) and рвов 11/31/14 (Joan).

35 Cecil T. Davis, The Monumental Brasses of Gloucestershire (Bath, 1899, facs. edition, 1969), 154-8.

36 Jordan, Philanthropy in England, Table I, 368.

37 The economic and social difficulties of the 1590s seems to have been accompanied in Gloucester by intense political factionalism of the sort which could well have motivated the ruling oligarchy to commission portraits of earlier leaders or benefactors as models of civil demeanor. Peter Clark, 'The Civic Leaders of Gloucester, 1580-1800', The Transformation of English Provincial Towns, 1600-1800, Peter Clark, ed. (London, 1984) 320-1.

38 Davis, 'The Monumental Brasses of Gloucestershire', 154-8.

39 Portraits of Richard Dobbs, Sir John Lemen, Sir Wolstan Dixie, and Lady Mary Ramsey herself hung in the school, as they do today, from the early seventeenth century. 
40 Portraits of Sir Peter Bessils, Robert Orpwood, Sir John Mason, Maud Teasdale, and Lionel Bostock, amongst others, hung by the 1620s, and are still in place today.

41 See a full list of civic portraits in schools, colleges and other civic institutions in Tittler, The Face of the City, Appendix A.

42 C.K. Manzione, Christ's Hospital of London, 1552-1598: a Passing Deed of Pity, (Selinsgrove, Pennsylvania and London, 1995), 124-5.

43 See wills of Lady Mary and Sir Thomas Ramsey; NA prob 11/98/191v-3v (1601) and рвов 11/75/307-08 (1590) respectively; Nicholas Carlisle, A Concise Description of the Endowed Grammar Schools in England and Wales, 2 vols (1818), 1.434; and Jordan, Charities of London, 102, 228. Amongst Lady Mary's bequests was her portrait of her husband, which went to a cherished cousin.

44 See in particular Paul Slack, 'Social Policy and the Constraints of Government, 1547-1558', The Mid-Tudor Polity, Jennifer Loach and Robert Tittler (eds) (Basingstoke, 1980), 108-14.

45 A hint of irony stems from the distinct possibility that she was actually illiterate. She 'signed' her will only with a mark, with a witness's signature next to it, though she may have been too ill at the time to write her name in full. РRов 11/98/191-3.

$46 O D N B$, vide Frankland; Jordan, Charities of London, 263-4.

47 Mrs. R.L. Poole, Catalogue of Portraits in the University, Colleges, City, and County of Oxford 3 vols. (Oxford, 1912-1926) 2.248-9.

48 Ibid, 2.248-9.

49 I am grateful to Joe Ward for helping me think this point through.

50 See, for example, David Howarth, Images of Rule, Art and Politics in the English Renaissance, 1485-1649 (Berkeley and Los Angeles, 1997); Foister, Holbein and England, 175-203; Foister, Holbein In England (London, 2005), 93-102; Lloyd and Thurley, Henry VIII, Images of a Tudor King; Elizabeth W. Pomeroy, Reading the Portraits of Queen Elizabeth I (Hamden, Ct., 1989); Roy Strong, The Tudor and Stuart Monarchy, 3 vols (London, 1995-1998).

51 See, for example, Lawrence Stone, The Crisis of the Aristocracy (Oxford, 1965), especially 712; Edward Chaney, The Evolution of English Collecting (New Haven, 2003); Elizabeth Goldring, 'The Earl of Leicester and Portraits of the duc d'Alencon', Burlington Magazine 146 (Feb. 2004), 108-11.

52 Whythorne, Autobiography, 134.

53 See Tittler, The Face of the City, passim. 